\title{
Antimicrobial Activity of Donkey Milk against Dermatomycotic Fungi and Foodborne Bacteria
}

\author{
Mostafa Koutb ${ }^{1,2,}$, Manal Khider ${ }^{3}$, Esam H. Ali ${ }^{1}$, Nemmat A. Hussein ${ }^{1}$ \\ ${ }^{1}$ Department of Botany \& Microbiology, Faculty of Science, Assiut University, Assiut, Egypt \\ ${ }^{2}$ Department of Biology, Faculty of Applied Science, Umm Al-Qura University, Mecca, Saudi Arabia \\ ${ }^{3}$ Department of Dairy Science, Faculty of Agriculture, Fayoum University, Fayoum, Egypt
}

\section{Email address:}

moskoutb@yahoo.com (M. Koutb)

${ }^{*}$ Corresponding author

\section{To cite this article:}

Mostafa Koutb, Manal Khider, Esam H. Ali, Nemmat A. Hussein. Antimicrobial Activity of Donkey Milk Against Dermatomycotic Fungi and Foodborne Bacteria. International Journal of Biomedical Materials Research. Vol. 4, No. 3, 2016, pp. 11-17. doi: 10.11648/j.ijbmr.20160403.11

Received: October 2, 2016; Accepted: October 11, 2016; Published: November 3, 2016

\begin{abstract}
The antimicrobial activity of donkey milk was examined against 3 bacterial and 3 fungal strains selected on the basis of their relevance as human pathogens. All samples of donkey milk exhibited antimicrobial activity against dermatomycotic fungi and foodborne pathogen bacteria. The highest antimicrobial activity was recorded against Trichophyton mentagrophytes and T. rubrum with minimal lethal concentration of $32 \mathrm{mg} / \mathrm{ml}$. In respect to foodborne pathogenic bacteria, Gram- positive bacteria (Bacillus cereus and Staphylococcus aureus) were more sensitive to donkey milk than Gram-negative bacteria (E. coli) with minimal lethal concentrations of 32, 64 and $128 \mathrm{mg} / \mathrm{ml}$ respectively. Donkey milk kept about 60 to $62 \%$ of its antimicrobial activity against $B$. cereus and $S$. aurous respectively, after digestion with pepsin $(2 \mathrm{mg} / \mathrm{ml})$, suggesting that the fatty acids of donkey milk has the highest antimicrobial effect. While the antimicrobial activity against dermatomycotic fungi and Gram-negative bacteria not affected after digestion with pepsin. To explain the antifungal capability of donkey milk against dermatomycotic fungi, fatty acids were analyzed by gas chromatography. Fatty acids analysis indicated that the major constituents in donkey milk lipid are oleic $(25.4 \%)$, palmitic $(23.75 \%)$, linolenic $(20.04 \%)$, arachidic $(3.58 \%)$ and stearic (3.26\%), which have antimicrobial activity. Finally, on the basis of results obtained in the current study, the antimicrobial activity of donkey milk against Staphylococcus aureus and dermatomycotic fungi, specially T. mentagrophytes and T. rubrum which frequently cause acute or chronic inflammatory tinea corporis; may be considered as a valuable natural product with novel functional protection properties in cosmetics and pharmaceutical industries.
\end{abstract}

Keywords: Donkey Milk, Trichophyton Mentagrophytes, Fatty Acids, Bacteria, Dermatomycotic Fungi

\section{Introduction}

Milk is a complex medium containing a variety of nutrients, minerals, vitamins as well as other molecules of functional or bioactive properties [1]. Donkey milk is considered to be helpful in the treatment of human immunerelated diseases; discovery of ass' milk properties find its roots in antiquity, when doctors recommended it to treat several afflictions, due to its healing and cosmetic virtues; Cleopatra, Queen of Ancient Egypt, took baths in donkey milk to preserve the beauty and youth of her skin and used in the manufacture of soaps and moisturizers. Also it is been found that Hippocrates (460-370 BC) prescribed donkey milk for several purposes, such as liver troubles, infectious diseases, fevers, edema, nose bleeds, poisonings and wounds. Trichophyton mentagrophytes and T. rubrum are the common causal agents of tinea, [2] while, Candida species were frequently isolated as causative agents of catheter-related bloodstream infections. In the last years, great interest has been developed toward donkey milk, because of its high likeness to human milk and unique functional properties with low casein content and high percentage of essential amino 
acids. Because of that, recently it is considered to be a good alternative to infant formulas, since its nutrient composition, particularly the proteins, are very similar to those of human milk $[1,3]$. Donkey milk contains a number of antimicrobial factors, especially milk proteins, which play a major role in milk protection. Enzymes, especially lysozyme, in donkey milk possess some unique characteristics such as bactericidal property which makes it different from other mammal milks $[3,4]$. The antimicrobial activity of donkey milk was reported previously against Salmonella choleraesuis and Shigella dysenteriae [5].

One of the defense factors in milk is free fatty acids which protect milk from different microbial infections [6]. Antimicrobial activity of fatty acids was stated to be dependent on chain length and unsaturation degree [7]. Longchain unsaturated fatty acids exhibit inhibitory activity against many bacteria even including methicillin-resistant $S$. aureus [8]. For instance, oleic and linoleic acids were reported as potent antibacterial [9]. However, milk and dairy products are great sources of saturated fatty acids; donkey milk appears to contain lower saturated fatty acids and higher amounts of essential fatty acids than cow milk. The role and the importance of donkey milk fatty acids are related to nutritional and extra-nutritional properties [10]. This study aims to (1) assess the antimicrobial activity of some Egyptian samples of donkey milks against the dermatomycotic fungi and some foodborne pathogenic bacteria, (2) to determine the minimal lethal concentration of donkey milks against tested pathogenic microorganisms, (3) to detect the major component corresponding to the antimicrobial activity of donkey milk.

\section{Materials and Methods}

\subsection{Milk Samples Collection}

Individual milk samples from different milk animals were collected from El-Minia and Fayoum governorates in Egypt. These milk types were; Buffalo, Donkey, Camel, Cow, Goat, and Sheep. Milk samples were collected immediately after milking in sterilized bottles and chilled in ice box to $4^{\circ} \mathrm{C}$, then stored at $-80^{\circ} \mathrm{C}$ until using.

\subsection{Chemical Composition}

Moisture, protein, fat, lactose, ash and total nitrogen (macro-kjeldahl method) were determined according to AOAC [11]. The $\mathrm{pH}$ values measured using $\mathrm{pH}$ meter (Kent EIL 7020) [12].

\subsection{Gas Chromatographic Analysis of Donkey Milk}

To evaluate fatty acids content of donkey milk, three analytical methods were used; DB- Wax, DB- 23 and HP- 88 methods [13]. Freeze dried milk samples (100 mg) were dissolved in $10 \mathrm{ml}$ hexane, and then $100 \mu \mathrm{l}$ of potassium hydroxide $(2.0 \mathrm{~N})$ was added. After centrifugation, clear supernatant was transferred into a $2.0 \mathrm{ml}$ autosampler vial. The analyses were performed in an Agilent 6890 GC
(University of Basilicata-Italy).

\subsection{Target Microorganisms}

Three fungal strains (Candida albicans DSM 2361, Trichophyton mentagrophytes AUMC 5505, T. rubrum AUMC 5488) and 3 bacterial strains (Bacillus cereus ATCC 14579, Staphylococcus aureus ATCC 8095 and Escherichia coli ATCC 25922) were used to investigate the antimicrobial activity of donkey milk samples. Bacteria and Candida strains were obtained from the Department of Agricultural Microbiology, Faculty of Agriculture, Fayoum University, Fayoum, Egypt, while, the other fungal strains were obtained from Assiut University Mycological Centre (AUMC), Assiut, Egypt. Stock cultures of bacteria were maintained on slants of nutrient agar. While, fungal cultures were maintained on slants of potato dextrose agar at $4^{\circ} \mathrm{C}$.

\subsection{Enzymatic Hydrolysis of Lysozyme in Donkey Milk}

To polish the antimicrobial activity of lysozyme fraction, hydrolysis of donkey milk was carried out in two steps [14]. Initially, donkey milk was acidified with $\mathrm{HCl}$ to a $\mathrm{pH} 3.5$, and then incubated with $2 \mathrm{mg} / \mathrm{ml}$ pepsin (Sigma) at $37^{\circ} \mathrm{C}$ for $2 \mathrm{~h}$. Then the enzymatic reaction was stopped by adjusting the $\mathrm{pH}$ to 8.0 with $0.5 \mathrm{M}$ sodium carbonate $(\mathrm{NaHCO} 3)$ solution, followed by heating at $75^{\circ} \mathrm{C}$ for $5 \mathrm{~min}$. The samples were cooled then kept at $4^{\circ} \mathrm{C}$ till used to determine the antimicrobial activity by agar disk diffusion method. As a control experiment, the lysozyme solution $(2 \mathrm{mg} / \mathrm{mL})$ was subjected to the process described above without the addition of pepsin.

\subsection{Antimicrobial Activity Test}

Antimicrobial activity of different milk types were assessed against fungal and bacterial strains by agar well diffusion method [15], [16]. For each bacterial or fungal strain, sterilized Mueller Hinton and potato dextrose agar medium were poured into sterilized Petri dishes, left to solidify at room temperature $\left(25^{\circ} \mathrm{C}\right)$, and then swabbed from fresh bacterial or fungal culture strain. Wells in the centre of agar plate were created using a sterile cork borer $(8 \mathrm{~mm})$ and loaded by $250 \mu \mathrm{l}$ of milk samples (concentrated to 50 folds by lyophilization and suspended in sterile water then pasteurized before tested). Plates with pathogenic bacteria or Candida albicans were incubated at $37^{\circ} \mathrm{C}$ and $30^{\circ} \mathrm{C}$ for $24 \mathrm{~h}$ respectively. Other pathogenic fungi were incubated at $30^{\circ} \mathrm{C}$ for $48-72 \mathrm{~h}$. The antimicrobial activity was determined by measuring the clear zones diameter (CZD) around each well in mm. Distilled water without test compounds was used as a control. Antibiotics such as Tetracycline $(30 \mu \mathrm{g})$, Chloramphenicol $(30 \mu \mathrm{g})$, Flucoral (fluconazole, $100 \mu \mathrm{g} / \mathrm{mL}$ ) and Mycosat (nystatin BP, 100 $\mu \mathrm{g} / \mathrm{mL}$ ) were used as references for comparison in antibacterial and antifungal tests, respectively. All experimental procedures were performed in triplicates. 


\subsection{Determination of Minimum Lethal Concentrations (MLC)}

The MLC of donkey milk was determined according to the dilution method described [17], [18]. For pathogenic bacteria or Candida albicans, serial of two-fold concentrations of donkey milk $(8,16,32,64,128,256$ and $512 \mathrm{mg} / \mathrm{ml})$ were pipetted into tubes containing $4 \mathrm{~mL}$ of LB or potato dextrose broth medium, respectively. Each tube was inoculated with $0.4 \mathrm{~mL}(0.5$ McFarland medium $)$ of a standardized suspension of bacterial test species containing $1 \times 10^{6}$ cell $/ \mathrm{ml}$. For fungi, liquid media was inoculated with a fungus strain and incubated for approximately $48 \mathrm{~h}$ at $30^{\circ} \mathrm{C}$. Subsequently, the culture was filtered through a thin layer of sterile sintered Glass G2 to remove mycelia fragments. The titer of spores of each fungus was determined microscopically using a hemocytometer. A suspension containing the spores was used for inoculation on PDA medium. Serial of two-fold concentrations of donkey milk were pipetted into tubes containing $4 \mathrm{~mL}$ of PD broth. Each tube was inoculated with $1 \times 10^{6}$ spores $/ \mathrm{ml}$.

All inoculated tubes were incubated at appropriate temperature and time for each strain of tested microorganisms. After the incubation period, $0.1 \mathrm{~mL}$ from each tube was subcultured on LB agar or PDA plates and incubated at appropriate temperature and time for each microorganism. The least concentration of tested donkey milk which gave a viable count less than $0.1 \%$ of the original inoculum $\left(1 \times 10^{6} \mathrm{cell} / \mathrm{ml}\right)$ was assumed as the MLC.

\section{Results and Discussion}

\subsection{Chemical Composition and Antimicrobial Activity of Milk Samples}

Data in Table 1 shows the gross composition of donkey milk compared to different milk types used in this experiment. In this study, the antimicrobial activity of donkey milk was examined against 3 bacterial and 3 fungal strains selected on the basis of their relevance as human pathogens. The examination of antimicrobial activity of the different milk samples by the agar diffusion method revealed that only donkey milk inhibited growth of most tested microorganisms. Different samples of donkey milk exhibited various degrees of antimicrobial activity against fungi and bacteria (Table 2 and Figure 1). Dermatomycotic fungi including Trichophyton rubrum are anthropophilic fungi which frequently cause acute or chronic inflammatory tinea corporis which is a superficial fungal infection (Dermatomycosis) of the arms and legs, especially on glabrous skin. The data in Table 2 and Figure 1 showed that different donkey milk samples had a significant antifungal potential against the tested dermatomycotic fungi. The highest antimicrobial activity of donkey milk was recorded against the dermatomycotic fungi including T. mentagrophytes (ranged from $17-25 \mathrm{~mm}$ ) and $T$. rubrum (ranged from 15-20 $\mathrm{mm}$ ) with minimal lethal concentration $32 \mathrm{mg} / \mathrm{ml}$. On the other hand, foodborne pathogen bacteria differed in their sensitivity to donkey milk samples tested, whereas, the Gram- positive bacteria were more sensitive than Gram-negative. The antibacterial activity of donkey milk against $B$. cereus and $S$. aureus ranged from $15-23$, and $17-20 \mathrm{~mm}$ with minimal lethal concentration of 32 and $64 \mathrm{mg} / \mathrm{ml}$ respectively, while, E. coli recorded the least inhibition zone values $(13-15 \mathrm{~mm})$ with minimal lethal concentration $128 \mathrm{mg} / \mathrm{ml}$ (Table 2). It is worthy to mention that the antimicrobial activity of donkey milk significantly decreased (38-40\%) after digestion with pepsin $(2 \mathrm{mg} / \mathrm{ml})$ and kept about 60 to $62 \%$ of its antimicrobial activity against $B$. cereus and $S$. aurous, respectively, suggesting that the fatty acids of donkey milk has the majority of the antimicrobial effect (Figure 2). Similar results were reported that monoglycerides of fatty acids possessed the most potent antimicrobial activity against $S$. aureus [19]. It has been indicated that, donkey's native and digested milk have different effects against two pathogenic bacterial strains; Escherichia coli and Listeria monocytogenes [20]. Lysozyme concentration in donkey milk reaches to $4000 \mathrm{mg} / \mathrm{l}$, whereas only traces were found in bovine milk [21]. Lysozyme is well known as an antibacterial protein. It catalyzes the hydrolysis of bacterial cell wall by cleavage of $\beta-1,4$ linkages between $\mathrm{N}$-acetylmuramic acid (NAM) and $\mathrm{N}$-acetylglucosamine (NAG) of peptidoglycan in the bacterial cell wall and acts as a nonspecific innate immunity molecule against the invasion of bacterial pathogens [22]. The in vitro antimicrobial activity of lysozyme is directed against certain Gram-positive bacteria such as Staphylococcus aureus, Micrococcus luteus, Bacillus stearothermophilus, Clostridium tyrobutyricum [23], and to a lesser degree against Gram-negative bacteria [24].

Table 1. Gross composition of the different milk types.

\begin{tabular}{llllllll}
\hline $\begin{array}{l}\text { Milk } \\
\text { types }\end{array}$ & Moisture\% & Fat\% & Protein \% & Lactose \% & Ash \% & pH \\
\hline Cow & 87.97 & 3.6 & 3.7 & 4.3 & 0.65 & 6.60 \\
Buffalo & 83.52 & 6.6 & 4.5 & 4.8 & 0.79 & 6.60 \\
Goat & 85.80 & 3.9 & 4.0 & 4.7 & 0.80 & 6.60 \\
Sheep & 81.80 & 7.2 & 5.6 & 4.6 & 0.82 & 6.60 \\
Donkey & 90.35 & 0.80 & 1.7 & 6.4 & 0.37 & 6.98 \\
\hline
\end{tabular}

Table 2. In vitro antibacterial and antifungal activities of tested milk samples against some dermatophytes fungi and bacterial strains indicated by clear zone diameter $(C Z D, m m)$ and minimal lethal concentration $(M L C, m g / m L)^{a, b}$

\begin{tabular}{|c|c|c|c|c|c|c|c|c|c|c|c|c|}
\hline \multirow{3}{*}{$\begin{array}{l}\text { Animal milk tested } \\
\text { (Average of } 10 \text { samples tested) }\end{array}$} & \multicolumn{6}{|c|}{ Pathogen Fungal strains tested } & \multicolumn{6}{|c|}{ Bacterial strains tested } \\
\hline & \multicolumn{2}{|c|}{$\begin{array}{l}\text { C. albicans } \\
\text { DSM } 2361\end{array}$} & \multicolumn{2}{|c|}{$\begin{array}{l}\text { T. mentagrophytes } \\
\text { AUMC } 5505\end{array}$} & \multicolumn{2}{|c|}{$\begin{array}{l}\text { T. rubrum } \\
\text { AUMC } 5488\end{array}$} & \multicolumn{2}{|c|}{$\begin{array}{l}\text { B. cereus } \\
\text { ATCC } 6633\end{array}$} & \multicolumn{2}{|c|}{$\begin{array}{l}\text { S. aureus } \\
\text { ATCC } 8095 \\
\end{array}$} & \multicolumn{2}{|c|}{$\begin{array}{l}\text { E. coli } \\
\text { ATCC } 25922\end{array}$} \\
\hline & CZD & MLC & CZD & MLC & CZD & MLC & CZD & MLC & CZD & MLC & CZD & MLC \\
\hline Donkey (sample 1) & - & - & 22 & 32 & 20 & 32 & 18 & 32 & 18 & 64 & 15 & 128 \\
\hline Donkey (sample 2) & - & - & 17 & 32 & 19 & 32 & 20 & 32 & 19 & 64 & 13 & 128 \\
\hline Donkey (sample 3) & - & - & 25 & 32 & 24 & 32 & 23 & 32 & 20 & 64 & 15 & 128 \\
\hline
\end{tabular}




\begin{tabular}{|c|c|c|c|c|c|c|c|c|c|c|c|c|}
\hline \multirow{3}{*}{$\begin{array}{l}\text { Animal milk tested } \\
\text { (Average of } 10 \text { samples tested) }\end{array}$} & \multicolumn{6}{|c|}{ Pathogen Fungal strains tested } & \multicolumn{6}{|c|}{ Bacterial strains tested } \\
\hline & \multicolumn{2}{|c|}{$\begin{array}{l}\text { C. albicans } \\
\text { DSM } 2361\end{array}$} & \multicolumn{2}{|c|}{$\begin{array}{l}\text { T. mentagrophytes } \\
\text { AUMC 5505 }\end{array}$} & \multicolumn{2}{|c|}{$\begin{array}{l}\text { T. rubrum } \\
\text { AUMC } 5488\end{array}$} & \multicolumn{2}{|c|}{$\begin{array}{l}\text { B. cereus } \\
\text { ATCC } 6633 \\
\end{array}$} & \multicolumn{2}{|c|}{$\begin{array}{l}\text { S. aureus } \\
\text { ATCC } 8095 \\
\end{array}$} & \multicolumn{2}{|c|}{$\begin{array}{l}\text { E. coli } \\
\text { ATCC } 25922\end{array}$} \\
\hline & CZD & MLC & CZD & MLC & CZD & MLC & CZD & MLC & CZD & MLC & CZD & MLC \\
\hline Donkey (sample 4) & - & - & 23 & 32 & 20 & 32 & 19 & 32 & 17 & 64 & 15 & 128 \\
\hline Donkey (sample 5) & - & - & 19 & 32 & 20 & 32 & 20 & 32 & 18 & 64 & 14 & 128 \\
\hline $\begin{array}{l}\text { Mixture of Donkey milk samples } \\
\text { (untreated) }\end{array}$ & - & - & 21 & 32 & 19 & 32 & 20 & 32 & 18 & 64 & 14 & 128 \\
\hline $\begin{array}{l}\text { Mixture of Donkey milk samples } \\
\text { (treated by pepsin) }\end{array}$ & - & - & 21 & 32 & 19 & 32 & 12 & 32 & 11 & 64 & 13 & 128 \\
\hline Cow $(10 \mathrm{mg})$ & - & - & - & - & - & - & - & - & - & - & - & - \\
\hline Buffalo (10 mg) & - & - & - & - & - & - & - & - & - & - & - & - \\
\hline $\begin{array}{l}\text { Sheep }(10 \mathrm{mg}) \\
\text { Antibiotics }\end{array}$ & - & - & - & - & - & - & - & - & - & - & - & - \\
\hline Mycosat (nystatin BP, $100 \mu \mathrm{g} / \mathrm{mL}$ ) & 22 & nd & 40 & nd & 37 & nd & - & nd & - & nd & - & nd \\
\hline Flucoral (fluconazole, $100 \mu \mathrm{g} / \mathrm{mL}$ ) & 27 & nd & 38 & nd & 34 & nd & - & nd & - & nd & - & nd \\
\hline Tetracycline $(30 \mu \mathrm{g})$ & - & nd & - & nd & - & nd & 26 & nd & 32 & nd & 34 & nd \\
\hline Chloramphenicol $30 \mu \mathrm{g}$ ) & - & nd & - & nd & - & nd & 33 & nd & 28 & nd & 21 & nd \\
\hline
\end{tabular}

${ }^{a}$ Each value represents mean of three replicats. ${ }^{b}$ Diameter of inhibition zone $(\mathrm{mm})$ was measured as the clear area centered on the agar well containing the sample, nd; not determined

Table 3. Fatty acids profile of Donkey milk.

\begin{tabular}{|c|c|c|c|}
\hline Fatty acid & Common name & Structural Formula & Percentage \\
\hline $\mathrm{C} 4: 0$ & Butyric acid & $\mathrm{CH}_{3}\left(\mathrm{CH}_{2}\right)_{2} \mathrm{COOH}$ & 1.829 \\
\hline C6:0 & Caproic acid & $\mathrm{CH}_{3}\left(\mathrm{CH}_{2}\right)_{4} \mathrm{COOH}$ & 1.068 \\
\hline C8:0 & Caprylic acid & $\mathrm{CH}_{3}\left(\mathrm{CH}_{2}\right)_{6} \mathrm{COOH}$ & 1.608 \\
\hline C10:0 & Capric acid & $\mathrm{CH}_{3}\left(\mathrm{CH}_{2}\right)_{8} \mathrm{COOH}$ & 3.000 \\
\hline C11:0 & Undecylic acid & $\mathrm{CH}_{3}\left(\mathrm{CH}_{2}\right)_{9} \mathrm{COOH}$ & 0.440 \\
\hline $\mathrm{C} 12: 0$ & Lauric acid & $\mathrm{CH}_{3}\left(\mathrm{CH}_{2}\right)_{10} \mathrm{COOH}$ & 2.248 \\
\hline C13:0 & Tridecylic acid & $\mathrm{CH}_{3}\left(\mathrm{CH}_{2}\right)_{11} \mathrm{COOH}$ & 0.310 \\
\hline C14:0 & Myristic acid & $\mathrm{CH}_{3}\left(\mathrm{CH}_{2}\right)_{12} \mathrm{COOH}$ & 2.669 \\
\hline C15:0 & Pentadecylic acid & $\mathrm{CH}_{3}\left(\mathrm{CH}_{2}\right)_{13} \mathrm{COOH}$ & 0.421 \\
\hline C16:0 & Palmitic acid & $\mathrm{CH}_{3}\left(\mathrm{CH}_{2}\right)_{14} \mathrm{COOH}$ & 23.753 \\
\hline C16:1 & Palmitoleic acid & $\mathrm{CH}_{3}\left(\mathrm{CH}_{2}\right)_{5} \mathrm{CH}=\mathrm{CH}\left(\mathrm{CH}_{2}\right)_{7} \mathrm{COOH}$ & 2.242 \\
\hline $\mathrm{C} 17: 0$ & Margaric acid & $\mathrm{CH}_{3}\left(\mathrm{CH}_{2}\right)_{15} \mathrm{COOH}$ & 0.459 \\
\hline $\mathrm{C} 17: 1$ & Heptadecenoic acid (cis-10) & $\mathrm{C}_{17} \mathrm{H}_{32} \mathrm{O}_{2}$ & 0.763 \\
\hline C18:0 & Stearic acid & $\mathrm{CH}_{3}\left(\mathrm{CH}_{2}\right)_{16} \mathrm{COOH}$ & 3.259 \\
\hline $\mathrm{C} 18: 1 \mathrm{t}$ & elaidic acid & $\mathrm{CH}_{3}\left(\mathrm{CH}_{2}\right)_{7} \mathrm{CH}=\mathrm{CH}\left(\mathrm{CH}_{2}\right)_{7} \mathrm{COOH}$ & 0.819 \\
\hline $\mathrm{C} 18: 1 \mathrm{c}$ & oleic acid & $\mathrm{CH}_{3}\left(\mathrm{CH}_{2}\right)_{7} \mathrm{CH}=\mathrm{CH}\left(\mathrm{CH}_{2}\right)_{7} \mathrm{COOH}$ & 25.395 \\
\hline C18: $2 \omega 6$ & Linolenic Acid & $\mathrm{C}_{18} \mathrm{H}_{32} \mathrm{O}_{2}$ & 20.040 \\
\hline C20:0 & Arachidic acid & $\mathrm{CH}_{3}\left(\mathrm{CH}_{2}\right)_{18} \mathrm{COOH}$ & 3.581 \\
\hline $\mathrm{C} 20: 2$ & eicosadienoic acid & $\mathrm{C}_{20} \mathrm{H}_{36} \mathrm{O}_{2}$ & 0.852 \\
\hline $\mathrm{C} 20: 3$ & Dihomo- $\gamma$-linolenic acid & $\mathrm{CH}_{3}\left(\mathrm{CH}_{2}\right)_{4} \mathrm{CH}=\mathrm{CHCH}_{2} \mathrm{CH}=\mathrm{CHCH}_{2} \mathrm{CH}=\mathrm{CH}\left(\mathrm{CH}_{2}\right)_{6} \mathrm{COOH}$ & 0.307 \\
\hline $\mathrm{C} 20: 4$ & Arachidonic acid & $\mathrm{CH}_{3}\left(\mathrm{CH}_{2}\right)_{4} \mathrm{CH}=\mathrm{CHCH}_{2} \mathrm{CH}=\mathrm{CHCH}_{2} \mathrm{CH}=\mathrm{CHCH}_{2} \mathrm{CH}=\mathrm{CH}\left(\mathrm{CH}_{2}\right)_{3} \mathrm{COOH}$ & 0.616 \\
\hline $\mathrm{C} 22: 2$ & Docosadienoic acid & $\mathrm{C}_{22} \mathrm{H}_{32} \mathrm{O}_{2}$ & 0.423 \\
\hline $\mathrm{C} 24: 0$ & Lignoceric acid & $\mathrm{CH}_{3}\left(\mathrm{CH}_{2}\right)_{22} \mathrm{COOH}$ & 0.330 \\
\hline
\end{tabular}

\subsection{Fatty Acids Analysis of Donkey Milk}

Fatty acids content of donkey milk (Table 3) were performed by using an Agilent 6890 GC mass spectrometry. The final results of GC/MS showed the separation of 23 compound FAME standard mixtures on the $60 \mathrm{~m} \times 0.25 \mathrm{~mm}$ ID, $0.15 \mu \mathrm{m}$. The major saturated fatty acids (Table 3 ) were palmitic acid (C16:0), arachidic acid (C20:0), stearic acid
(C18:0), capric acid (C10:0), myristic acid (C14:0), lauric acid (C12:0) which were 23.75, 3.58, 3.26, 3.0, 2.67 and $2.25 \%$, respectively. While, the major unsaturated fatty acids

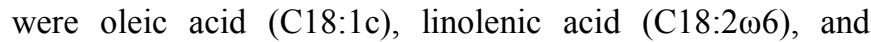
palmitoleic acid (C16:1) which were $25.4 \%, 20.04$ and 2.24, respectively. It has been found that palmitic and palmitoleic acids represent 26.3 and $2.25 \%$ respectively [25]. Also it has been found that palmitic acid represents $18.33-22.37 \%$ [26]. 
The chemical composition of donkey milk revealed that the lipid fraction was characterized by high levels of linoleic (average $8.15 \mathrm{~g} \cdot 100 \mathrm{~g}-1$ of total fatty acids) and linolenic acid with an average $6.32 \mathrm{~g} \cdot 100 \mathrm{~g}-1$ of total fatty acids. The essential fatty acids (linoleic and linolenic acids) were the most represented components of the poly-unsaturated fatty acids class in donkey's milk [27] showing higher values than human milk and that of the other animal species. So, donkey's milk can be considered a functional food for human nutrition and its potential utilization for infant nutrition as well as adult diets, particular for the elderly [26], [36].

Fatty acids are widely occurring in natural fats and dietary oils and they are known to have antibacterial and antifungal properties. Fatty acid methyl ester extracts of Excoecaria agallocha have been reported to possess antibacterial and antifungal activities against Bacillus subtilis, Staphylococcus aureus, Escherichia coli, Klebsiella pneumonia, Candida albicans, C. krusei, C. tropicalis. This extract was rich in palmitic, luric acids and also contains myristic, stearic, pentadecanoic, heptadecanoic acids and lower amount of arachidic acid [28].

The antibacterial effect of fatty acids has been studied against 12 strains, which cause oral pathogens and they found that $\omega-3$ PUSFAs and $\omega-6$ PUSFAs showed an antibacterial effect against 11 of them [29]. Donkey milk fat contains $9.5 \%$ free fatty acids, while cow, sheep, goat and human milk fat have low levels of free fatty acids (0.7-1.5\%) [30], [31]. Compared to ruminants, donkey milk fat contains a higher percentage of polyunsaturated fatty acids (PUFA) and a lower percentage of saturated fatty acids (SFA) and monounsaturated fatty acids (MUFA). In absolute values, donkey milk contains on average $1.69 \mathrm{~g} / 1$ PUFA, $5.46 \mathrm{~g} / \mathrm{l}$ SFA and $1.96 \mathrm{~g} / \mathrm{l}$ MUFA compared to respectively $5.78,15.2$ and $16.9 \mathrm{~g} / \mathrm{l}$ in human milk and $1.31,25.8$ and $9.2 \mathrm{~g} / 1$ in bovine milk [25]. The fatty acids of horse and donkey milk are mainly unsaturated or short-chained, which is interesting from a nutritional point of view. Horse and donkey milks have additionally higher levels of linoleic acid (n 6 C18: 2) and a-linolenic acid (n-3 C18: 3) than bovine milk (respectively 5 and 224 times more) [32]. The antifungal activities exhibited by linolenic, linoleic and oleic acids may be useful in controlling important plant pathogens [33].

It was indicated that $\mathrm{C} 12$ (lauric acid) is the most inhibitory saturated fatty acid against gram-positive organisms [34].

Although lysozyme is designated as the main antimicrobial agent in donkey milk owing to its high concentration some fatty acids which have already been determined in donkey milk could be important for overall antibacterial [35]. Longchain polyunsaturated fatty acids are attracting attention as potential new topical treatments for Gram-positive infections due to their antimicrobial potency and anti-inflammatory properties. It has been found that $S$. aureus cells were killed within 15-30 min during exposure to the Long-chain polyunsaturated fatty acids [36], [37]. In addition it was demonstrated that fatty acid and monoglycerides with 8-12 carbons were more strongly antiviral and antibacterial when added to milk and infant formula than long chain monoglycerides [38]. Moreover it has been found that linoleic, lauric and oleic acid among the detected fatty acids in donkey milk have antibacterial activity against Listeria monocytogenes and Staphylococcus aureus [39].

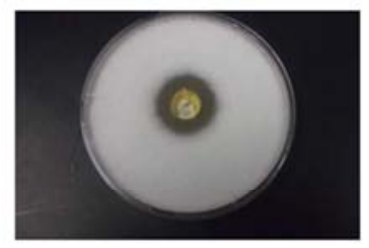

Trchophyton mentagrophtes (AUMC 5505)

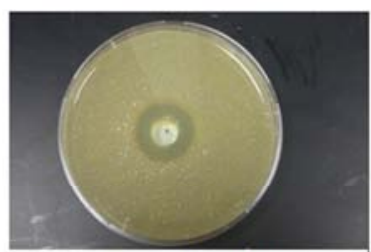

B. cereus ATCC 14579

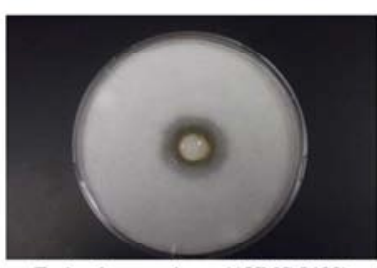

Trchophyton rubrum (AUMC 5488)

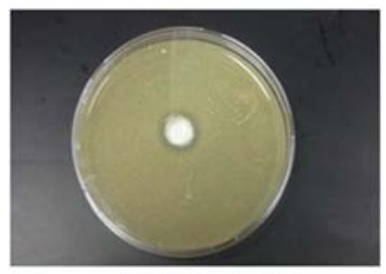

C. albicans DSM 236

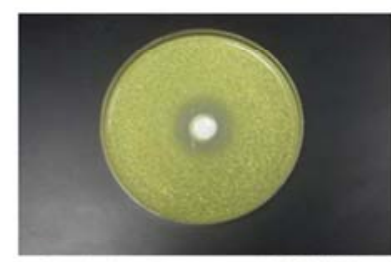

Staphylococcus aureus ATCC 8095

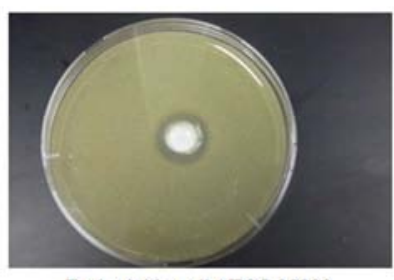

Escherichia coli ATCC 25922

Figure 1. Antimicrobial activities of Donkey milk against some Dermatophytes fungi and Foodborne bacterial strains indicated by clear zone diameter (CZD, mm). All tests were conducted in triplicate. 


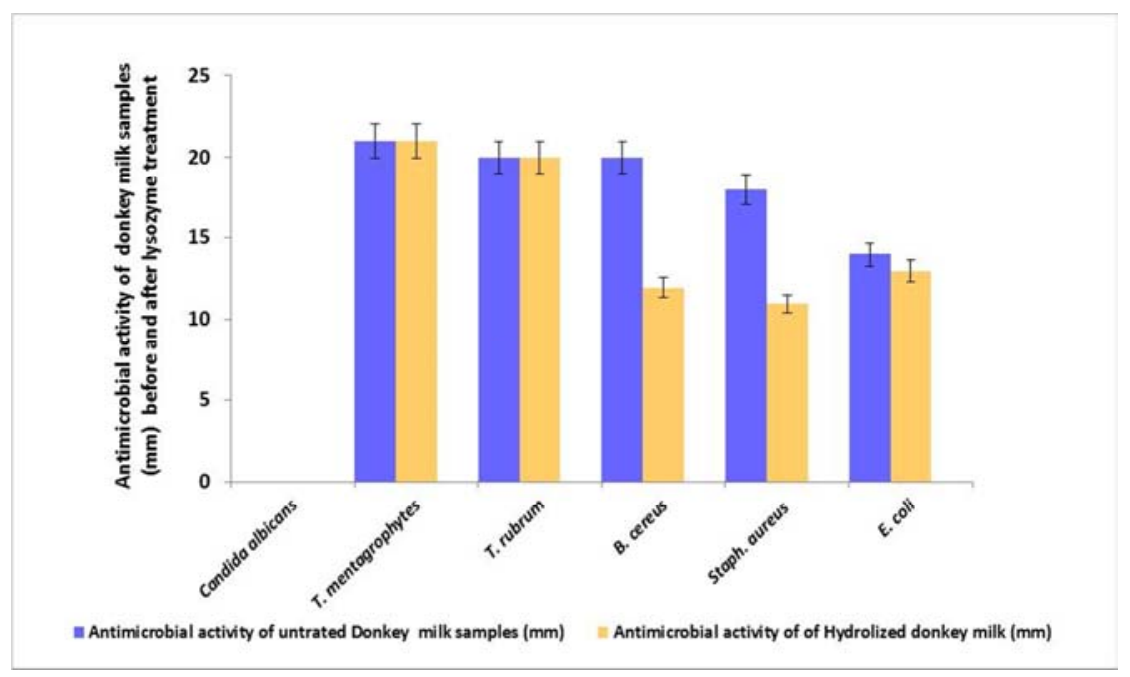

Figure 2. Antimicrobial activity of donkey milk samples (mm) before and after lysozyme treatment.

\section{Conclusion}

Finally, on the basis of results obtained in this study, the antimicrobial activity of donkey milk against Staphylococcus aureus and the dermatomycotic fungus Trichophyton rubrum which frequently cause acute or chronic inflammatory tinea corporis; may be considered as a valuable natural product with novel functional properties in cosmetics and pharmaceutical industries.

\section{Acknowledgements}

The authors would like to thank Dr. Rosanna Paolino and Dr. Hazem Elshafie, (University of Basilicata-Italy) for their help to analyze fatty acids composition of donkey milk by GC mass spectrometry.

\section{References}

[1] Tafaro A, Magrone T, Jirillo F, Martemucci G, D'Alessandro AG, Amati L, Jirillo E. Immunological properties of donkey's milk: its potential use in the prevention of atherosclerosis. Curr Pharm Des 2007;13:3711-3717.

[2] Weitzman I, Summerbell RC. The Dermatophytes. Clinical Microbiology Reviews 1995;8(2):240-259.

[3] Vincenzetti S, Polidori P, Mariani P, Cammertoni N, Fantuz F, Vita A. Donkey's milk protein fractions characterization. Food Chemistry 2008;106:640-649.

[4] Saríc LC, Saríc BM, Mandíc AI, Torbica AM, Tomi LM, Cvetkovi DD. Antibacterial properties of Domestic Balkan donkeys' milk. International Dairy J 2012;25:142-146.

[5] Zhang XY, Zhao L, Jiang L, Dong ML, Ren FZ. The antimicrobial activity of donkey milk and its microflora changes during storage. Food Control 2008;19:1191-1195.

[6] Benkerroum N, Mekkaoui M, Bennani N, Hidane K. Antimicrobial activity of camel's milk against pathogenic strains of Escherichia coli and Listeria monocytogenes. International Journal of Dairy Technology 2004;57:39-43.
[7] Benkendorff K, Davis AR, Rogers CN, Bremner JB. Free fatty acids and sterols in the benthic spawn of aquatic mollusks and their associated antimicrobial properties. J Exp Marine Biol Ecol 2005;316:29-44.

[8] Farrington M, Brenwald N, Haines D. Resistance to desiccation and skin fatty acids in outbreak strains of methicillin-resistant Staphylococcus aureus. J Med Microbiol 1992;36:56-60.

[9] Zheng CJ, Yoo JS, Lee TG. Fatty acid synthesis is a target for antibacterial activity of unsaturated fatty acids. FEBS Lett 2005;579:5157-5162.

[10] Chiofalo B, Salimei E, Chiofalo L. Acidi grassi nel latte d.asina: proprietà bionutrizionali ed extranutrizionali. Large Animal Review 2003;6:21-26.

[11] AOAC. Association of Official Analytical Chemists. Official Methods of Analysis. 17 $7^{\text {th }}$ ed. Washington, DC, USA 2000.

[12] Kosikowski FV. Cheese and Fermented Milk Foods. (2 ${ }^{\text {nd }}$ ed.), F.V. Kosikowski and Associates, Brooktondale, New York, USA, 1982; pp. 329-333.

[13] David F, Sandra P, Vickers AK. Column selection for the analysis of fatty acid methyl esters. Agilent Technologies August 30, 5989- 3760EN 2005.

[14] Thammasirirak S, Pukcothanung Y, Preecharram S, Daduang S, Patramanon R, Fukamizo T, Araki T. Antimicrobial peptides derived from goose egg white lysozyme. Comparative Biochemistry and Physiology, Part C 2010;15:84-91.

[15] Torres A, Garedew A, Schmolz E, Lamprecht I. Calorimetric investigation of the antimicrobial action and insight into the chemical properties of "angelita" honey- a product of the stingless bee Tetragonisca angustula from Colombia. Thermochim Acta 2004;415:107-113.

[16] Elbanna K, Attalla K, Elbadry M, Abdeltawab A, GamalEldin H, Ramadan M. Impact of floral sources and processing on the antimicrobial activities of different unifloral honeys. Asian Pacific J of Tropical Disease 2014;4(3):194-200.

[17] Jobran ELR, Finegold SM. Diagonative Microbiology. $9^{\text {th }}$ ed. part 2 pp: 168-188. Mosby Saint Louis, USA 1994. 
[18] Assiri A, Elbanna K, Al-Thubiani A, Ramadan M. Coldpressed oregano (Origanum vulgare) oil: a rich source of bioactive lipids with novel antioxidant and antimicrobial properties. Eur Food Res Technol 2016;242:1013-1023.

[19] Zhang H, Zhang L, Peng1 L, Dong X, Wu D, Wu VC, Feng F. Quantitative structure-activity relationships of antimicrobial fatty acids and derivatives against Staphylococcus aureus. J Zhejiang Univ-Sci B (Biomed \& Biotechnol) 2012;13(2):8393.

[20] Tidona F, Sekse C, Criscione A, Jacobsen M, Bordonaro S, Marletta D, Vegarud GE. Antimicrobial effect of donkeys' milk digested in vitro with human gastrointestinal enzymes. International Dairy J 2011;21:158-165.

[21] Guo HY, Pang K, Zhang XY, Zhao L, Chen SW, Dong ML. Composition, physiochemical properties, nitrogen fraction distribution, and amino acid profile of donkey milk. J of Dairy Science 2007;90:1635-1643.

[22] Jollès P, Jollès J. What's new in lysozyme research? Always a model system, today as yesterday. Mol Cell Biochem $1984 ; 63(2): 165-189$.

[23] Cunningham L, Bowles NE, Archard LC. Persistent virus infection of muscle in postviral fatigue syndrome. $\mathrm{Br}$ Med Bull 1991;47:852-871.

[24] Banks JG, Board RG, Sparks NH. Natural antimicrobial systems and their potential in food preservation of the future. Biotechnol Appl Biochem 1986;8:103-147.

[25] Gastaldi D, Bertino E, Monti G, Baro C, Fabris C, Lezo A. Donkey's milk detailed lipid composition. Frontiers in Bioscience 2010;E2:537-546.

[26] Martemucci G, D’Alessandro AG. Fat content, energy value and fatty acid profile of donkey milk during lactation and implications for human nutrition. Lipids in Health and Disease 2012;11(113):1-14.

[27] Chiofalo B, Azzara V, Venticinque L, Piccolo D, Chiofalo L. Variations of fatty acids in Ragusana ass.s milk during lactation. $55^{\text {th }}$ Annual Meeting of the EAAP, September $5^{\text {th }}$ $9^{\text {th }}, 2004$, Bled, Slovenia. 2004;Session:H4.16.

[28] Agoramoorthy G, Chandrasekaran M, Venkatesalu V, Hsu M.J. Antibacterial and antifungal activities of fatty acids methyl esters of the Blind-your-eye Mangrove from India. Brazilian J of Microbiol 2007;38:739-742.
[29] Choi JS, Park NH, Hwang SY, Sohn JK, Kwak I, Cho KK, Choi IS. The antibacterial activity of various saturated and unsaturated fatty acids against several oral pathogens. $J$ of Environmental Biology 2013;34:673-676.

[30] Park SE, Yoo HS, Jin CY. Induction of apoptosis and inhibition of telomerase activity in human lung carcinoma cells by the water extract of Cordyceps militaris. Food Chem Toxicol 2009;47(7):1667-1675.

[31] Uniacke-Lowe T. Studies on equine milk and comparative studies on equine and bovine milk systems. PhD thesis. Cork: University College Cork 2011.

[32] Salamon RV, Salamon Sz, Csapó-Kiss ZS, Csapó J. Composition of mare's colostrums and milk. I. Fat content, fatty acid composition and vitamin contents. Acta Universitatis Sapientiae, Alimentaria 2009;2:119-131.

[33] Walters D, Raynor L, Mitchell A, Walker R, Walker K. Antifungal activities of four fatty acids against plant pathogenic fungi. Mycopathol 2004;157(1):87-90.

[34] Kabara JJ, Swieczkowski DM, Conley AJ, Truant JP. Fatty Acids and Derivatives as Antimicrobial Agents. Antimicrobial Agents and Chemotherapy 1972;2(1):23-28.

[35] Salimei E, Fantuz F. Equid milk for human consumption. International Dairy J 2012;24:130-142.

[36] Desbois AP, Lawlor KC. Antibacterial Activity of long-chain polyunsaturated fatty acids against Proionibacterium acnes and Staphylococcus aureus. Mar Drugs 2013;11(11):45444557.

[37] Andrew P, Desbois AP, Lawlor KC. Antibacterial Activity of Long-Chain Polyunsaturated Fatty Acids against Propionibacterium acnes and Staphylococcus aureus. Mar. Drugs 2013;11:4544-4557.

[38] Isaacs CE, Litou RE, Thormar H. Antimicrobial activity of lipids added to human milk, infant formula, and bovine milk. J Nutr Chem 1995;6:362-366.

[39] Saríc LC, Saríc BM, Kravić SZ, Plavšić DV, Milovanović ILJ, Gubić JM, Nedeljković NM. Antibacterial activity of Domestic Balkan donkey milk toward Listeria monocytogenes and staphylococcus aureus. Food and Feed Research 2014;41(1):47-54. 